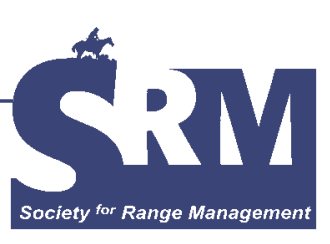

\title{
Natural Resource Management on the Other Side of the World: The Nagorno Karabakh Republic
}

\section{By Steven H. Sharrow}

N

estled on the slopes and in the valleys of the southern Caucasus Mountains in Central Asia, the Nagorno Karabakh Republic (NKR) could well have been the model for James Hilton's Shangri-La in his novel "Lost Horizon." Like Shangri-La, the steep mountains that provide its basic character have also served to isolate it from the outside world. Uplift of the Caucasus Mountains began approximately 5 million years ago as the Arabian Plate collided with the Eurasian Plate. ${ }^{1}$ Mountain building continues today as the Arabian Plate moves $\mathrm{NNE}$ at about $28 \mathrm{~mm}$ per year. The resulting mountains are relatively young and steep. Slopes commonly exceed $100 \%$. Earthquakes, such as the devastating 6.9-magnitude trembler of 1988 centered over a thrust fault near Spitak, Armenia, are characteristic of the region's active mountain uplift.

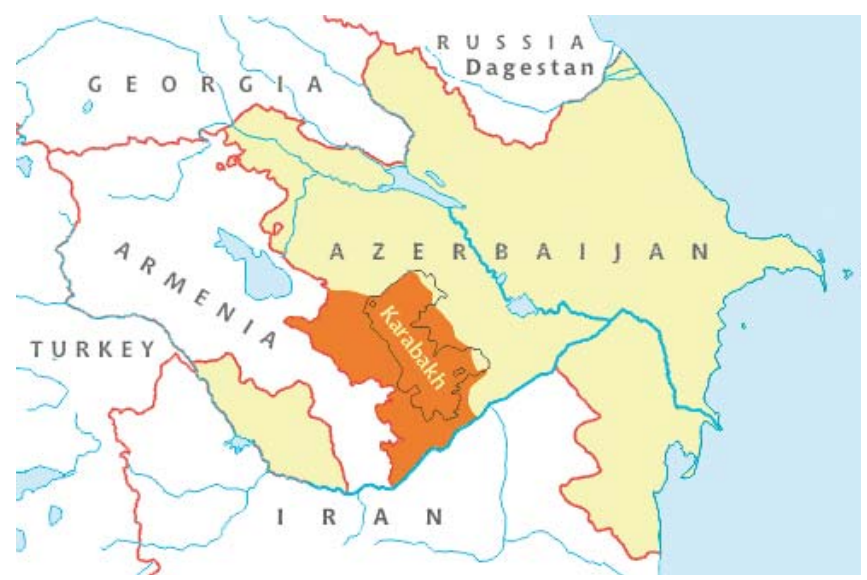

Figure 1. Territory controlled by the Nagorno Karabakh Republic and the traditional boarders of the Karabakh Autonomous Region. (Source: Wikipedia, http://en.wikipedia.org/wiki/Image:Az-qa-kaart-en.PNG).

\begin{tabular}{|c|c|}
\hline Common name & Scientific name \\
\hline Brown bear & Ursus arctos \\
\hline Caucasus panther & $\begin{array}{l}\text { Panthera pardus } \\
\text { ciscaucasica }\end{array}$ \\
\hline Golden eagle & Aquila chrysaetos \\
\hline Grey wolf & Canis lupis \\
\hline Lynx & Lynix lynix \\
\hline
\end{tabular}

The highest point in Karabakh is mount Gomshasar at 3,700 $\mathrm{m}$. The Karabakh range also includes 4 other peaks over 2,400 $\mathrm{m}$ in elevation. With the Black Sea to the west and the Caspian Sea to the east, the Caucasus Mountains have long blocked movement of humans as well as plants and animals within this natural corridor between Europe and Asia (Fig. 1). The mixing of Mediterranean, Asian, and European species within relatively isolated mountain valleys has made the Caucasus region one of the world centers of biodiversity with over 6,300 plant species, ${ }^{2} 1,600$ of which are found nowhere else in the world (are endemic). This places the Caucasus among the richest floristic regions in the temperate zone. ${ }^{3}$ Fauna of the Caucasus is equally diverse with 152 species of mammals (32 endemic), 389 species of birds ( 3 endemic), 79 reptile species (21 endemic), 13 amphibian species, and over 14,000 species of invertebrates. ${ }^{4}$ The mountain forests provide refuge to predators that are becoming scarce elsewhere in Central Asia and Europe, such as the gray wolf, lynx, golden

This article has been peer reviewed. 


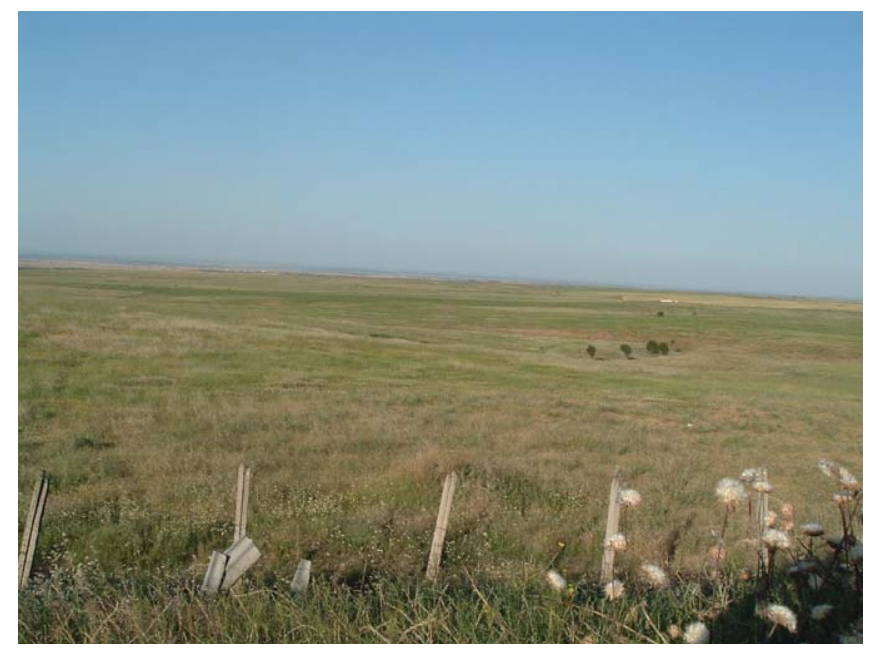

Figure 2. Former grape vineyards on upper slopes of the Caspian Plain south of Mardakert, NKR. Natural vegetation is sagebrush-steppe.

eagle, and the increasingly rare Caucasus leopard (Table 1). People in NKR are very environmentally aware and highly value their clean mountain environment. This region is a locus of long life where people often live to be over 100 years old. Low environmental pollution undoubtedly contributes to this longevity.

Lying between $39^{\circ}$ and $40^{\circ}$ north latitude, NKR has a relatively mild subtropical climate. Rainfall is fairly evenly distributed across the year with $28 \%$ of total annual precipitation occurring in fall (September-November), $12 \%$ in winter (December-February), 32\% in spring (March-May), and $28 \%$ in early summer (June-August). Summer thunderstorms frequently bring damaging hail storms, especially in the foothills and mountains of the Karabakh range. Winter temperatures in lower elevations seldom remain below freezing, and people are able to grow subtropical fruits such as citrus, pomegranates, and figs in their home gardens.

Unfortunately, rising from the ashes of the former Soviet Union has proven to be a daunting challenge for this small democratic nation. The region that now includes NKR and

\begin{tabular}{|c|c|}
\hline Common name & Scientific name \\
\hline Annual ryegrass & Lolium rigidum \\
\hline Black-wood & Cotoneaster racemiflora \\
\hline Buckthorn & Rhamnus spp. \\
\hline Bulbous bluegrass & Poa bulbosa \\
\hline Fescue & Festuca spp. \\
\hline Hawthorn & Crataegus spp. \\
\hline Junegrass & Koeleria spp. \\
\hline Needlegrass & Stipa spp. \\
\hline Wheatgrass & Agropyron spp. \\
\hline Sagebrush & Artemisia spp. \\
\hline
\end{tabular}

Azerbaijan was acquired by czarist Russia from the Persian Empire by the treaty of Gulistan in 1813. Following the Bolshevik Revolution of 1914-1917, peace negotiations to end World War I, and the Bolshevik invasion of Azerbaijan and Armenia in 1920, Karabakh was eventually incorporated as an ethnic Armenian Autonomous Region within the predominantly Turkish Soviet Socialist Republic of Azerbaijan, where it remained until the breakup of the Soviet empire in 1991. Deep-seated ethnic tensions between ethnic Armenians and the Turkish majority population in Azerbaijan flared up in 1988. The resulting violent civil unrest contributed materially to the collapse of the Soviet Union. Karabakh declared its independence from Azerbaijan in 1991. The 4 years of civil war that followed was finally halted by a cease-fire in 1994. To date, the political issues that spawned the war have not been resolved, so no peace treaty has been signed, and no foreign government other than Armenia has diplomatic or trade relations with NKR. Lack of formal international recognition extends to establishing the territorial boarders of the nation. The NKR claims a central homeland of approximately $5,000 \mathrm{~km}^{2}$ in the mountains and foothills of the Karabakh range, a small portion of which is held militarily by Azerbaijan. In addition, NKR controls another $12,000 \mathrm{~km}^{2}$ of "occupied land" in the mountains between NKR and Armenia and in the sloping plains above the Caspian Sea. Lack of foreign trade relations has only added to NKR's natural geographic isolation. Physical access to NKR is presently limited to a single winding mountain "road of life" linking Goris, Armenia, to Stepanakert, NKR's capital. There are no operational civilian airports in NKR. The 300-km drive from the nearest airport in Yerevan, Armenia, to Stepanakert takes 5-6 hours. The nearest ocean access is through Armenia to the Mediterranean by way of the Black Sea ports of Georgia or to the Indian Ocean through Iranian ports on the Persian Gulf.

Land reform was initiated quickly after independence. The government recognizes 3 types of land: government land, village land, and private land. Private lands were issued to each person residing within NKR. Each person received $6,000 \mathrm{~m}^{2}$ of land, making the average family farm about 3 ha in size. Villages often received 1,000-3,000 ha of land based on their size and traditional land use. This land may be rented for individual use under leases ranging from 1 to 25 years. All other lands belong to the government and may be used if appropriate under government land use policies. Most agricultural equipment was lost during the war for independence. That remaining was transferred to private operators that currently do custom operations for farmers for a set fee per hectare treated. Farm equipment is old and tired, and custom charges to farmers are relatively high compared to the value of crops obtained. This appears to be as much a problem of low crop yields as it is one of low prices received for crops.

There has been a long human presence in Karabakh. It is a country of small villages, many of which were founded prior 


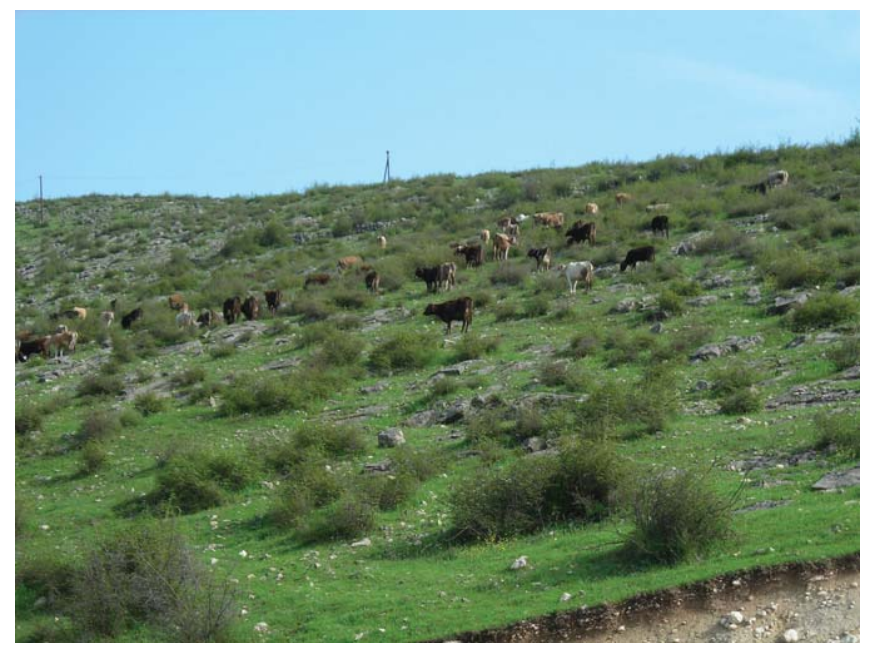

Figure 3. Mesic mixed shrub-steppe in foothills near Hardrut, NKR.

to the 13th century. Although most villages have fewer than 500 people, their high number have supported a considerable population of rural farmers. Approximately $70 \%$ of NKR's 140,000 current inhabitants are rural farmers. Karabakh was a significant commercial contributor of wheat, grapes, and animal products to the Soviet central economy. Most land suitable for farming has been plowed, and areas suitable for grazing have been grazed or hayed. Therefore, the vegetation largely reflects this past use. It is difficult to find unimpacted reference areas to judge what the "potential natural community" might be without human interference. Therefore, observations of present vegetation plus plant community descriptions of similar sites in the Caucasus region ${ }^{3,5}$ are used to broadly define 3 agroclimatic zones: foothill grassland, lower mountain mixed hardwood forest, and mountain subalpine grassland.

The foothill grasslands once occupied the generally eastern facing foothills and lower slopes of the mountains at about 300-600 m elevation (Fig. 2; Table 2). Annual precipitation is approximately $250-400 \mathrm{~mm}$. Shrubs were an

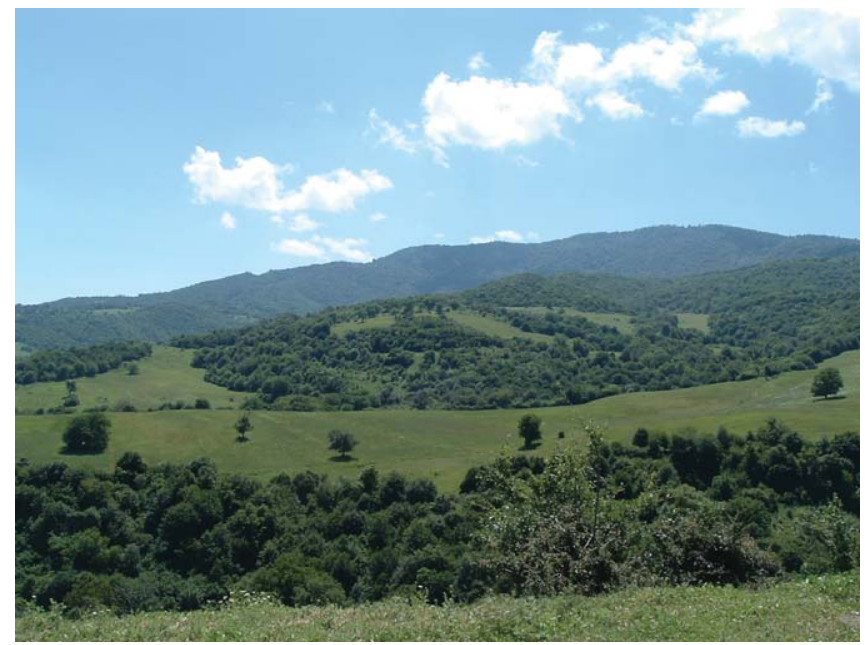

Figure 4. Old wheat fields interspersed with midelevation mixed hardwood forest in northeastern NKR.
Table 3. Common plants of the lower mountain forest zone

\begin{tabular}{|l|l|}
\hline Common name & Scientific name \\
\hline Ash & Fraxinus spp. \\
\hline Beech & Fagus spp. \\
\hline Birch & Betula spp. \\
\hline Cherry & Prunus spp. \\
\hline Elm & Ulmus spp. \\
\hline Hornbean & Carpinus spp. \\
\hline Linden & Tilia spp. \\
\hline Maple & Acer spp. \\
\hline Oak & Quercus spp. \\
\hline Poplar & Populus spp. \\
\hline Walnut & Jugulans spp. \\
\hline
\end{tabular}

important component of these communities. Cool-season grasses, such as bulbous bluegrass, annual ryegrass, perennial fescues, needlegrass, junegrass, and wheatgrass, occurred with several types of woody and herbaceous sagebrush in the more xeric areas and with shrubs such as buckthorn, hawthorn, and black-wood in the more mesic areas (Fig. 3). This is the major dryland cereal zone of Karabakh. It is currently used to grow winter wheat. Potential wheat yields range from $6,000 \mathrm{~kg} / \mathrm{ha}$ on the most productive lower slopes to 2,500 $\mathrm{kg} / \mathrm{ha}$ on the upper slopes. However, current yields are well below these levels because of declining use of fertilizer and lack of improved seed varieties. Average wheat yields in NKR are currently about $1,900 \mathrm{~kg} / \mathrm{ha} .{ }^{6,7}$ During Soviet times, the Transcaucasus Canal brought water from the Tartar River to irrigate 14,000 ha of wine grapes in the foothill zone near Mardakert. Closure of a section of the canal where it crosses Azerbaijan has killed most of these vineyards. They have now been converted to rain-fed wheat fields. Fruits such as grapes pomegranates, figs, pears, apricots, and peaches are currently grown in small orchards where irrigation water is available.

The lower mountain zone is generally found at $600-1,100$ $\mathrm{m}$ elevation and receives approximately $400-600 \mathrm{~mm}$ annual precipitation (Fig. 4; Table 3). Hills are covered with mixed hardwood forests of oak, beech, wild cherry, hornbean, maple, elm, and linden, with poplar, ash, birch, and walnut in moister areas. Broad areas of forest still exist on steep slopes. Moderate slopes have often been cleared for use as crop or hay fields, forming large openings in the forest. Cereals such as oats, wheat, and barley were grown dryland, and corn for livestock feed was grown with irrigation during Soviet times. Most of this cropland is now used to grow winter wheat or left unplanted to serve as go-back pasture. Winter wheat yields are low $(1,000-2,000 \mathrm{~kg} / \mathrm{ha})$, and agricultural equipment is not reliably available to plant and harvest crops. Oats and spring barley are no longer grown, and large areas of former cropland have been returned to early successional pasture because tractors and harvesters are not reliably available. 
Table 4. Common plants of the subalpine zone

\begin{tabular}{l|l|}
\hline Common name & Scientific name \\
\hline Bentgrass & Agrostis capillaris \\
\hline Bluegrass & Poa nemoralis \\
\hline Bogsedge & Kobresia spp. \\
\hline Clover & Trifolium spp. \\
\hline Dandelion & Taraxacum stevenii \\
\hline False brome & Brachypodium silvaticum \\
\hline Junegrass & Koeleria spp. \\
\hline Lady's-mantle & Alchemilla caucasica \\
\hline Mountain brome & Bromus spp. \\
\hline Orchard grass & Dactylis glomerata \\
\hline Reed grass & Calamagrostis arundinacea \\
\hline Sedge & Carex spp. \\
\hline Sheep fescue & Festuca ovina \\
\hline Speedwell & Veronica gentianoides \\
\hline Sweet clover & Melilotis spp. \\
\hline Vetch & Vicia spp. \\
\hline Yarrow & Achillea spp. \\
\hline
\end{tabular}

Forests occupy about $36 \%$ of NKR. They are used to graze livestock, especially pigs. Little forest floor vegetation or tree reproduction may be present because of foraging by livestock as well as dense overhead tree canopies. Fuel wood is a major source of heat for rural homes. Firewood cutting is allowed in forests, but the high permit fee charged per cubic meter of fuel wood taken limits domestic wood use. Unauthorized cutting of large trees was discouraged by forest use zoning during Soviet times ${ }^{3}$ and is currently forbidden by a NKR law signed in 2000. Forests often contain large commercially valuable trees. Armenia is currently liquidating its inventory of large hardwood trees for sale to Europe. This process has been greatly hampered in NKR by lack of market access. However, there is concern that "high grading" the most valuable large trees may spread into NKR forests. ${ }^{8}$ For example, a news story in $\mathrm{NKR}^{9}$ exposed logging of large old trees that recently occurred under the guise of "salvage logging" to remove diseased trees. The concern is not about deforestation because only large trees of valuable species, such as linden, oak, and walnut, are being cut. The problem is with reduced "quality" of forests as the large trees that give the forest its characteristic structure are removed. There are no forest tree nurseries in NKR, so replanting is not practiced. Inventory of present forest resources as well as more effective regulation of forest practices are needed to preserve NKR's forest heritage.

The subalpine zone generally is found above $1,100 \mathrm{~m} \mathrm{el}-$ evation. Average annual precipitation is $600-800 \mathrm{~mm}$. Vegetation is predominantly cool-season short and midgrasses with a significant component of perennial forbs and native legumes (Table 4). Orchard grass, junegrass, bentgrass, reed grass, clovers, bluegrass, vetch, yarrow, false brome, and sweet clover are typical lower-elevation plants (below 2,400 $\mathrm{m}$ ) within the zone. Sedges, sheep fescue, mountain brome, bogsedge, speedwell, lady's-mantle, and dandelion are common in the higher portions of the zone. Grazing and haying are the most common agricultural uses of this zone (Fig. 5). However, some limited potato production occurs in the lower elevations on deeper soils. Large white mushrooms are collected during spring from subalpine grassland and sold from small stands along roadsides.

There is a small deposit of gold and some other commercially useful minerals (marble and limestone), but NKR's main economic assets are hydropower and agriculture. The steep mountains support streams that have significant potential for generating electricity. Currently, NKR produces sufficient electricity to meet its own needs and exports power to Armenia. All villages have electricity that provides their lighting and heating needs. Agriculture has long been the economic lifeblood of Karabakh. Unfortunately, the region has gone from being a significant exporter of agricultural produce during Soviet times to importing $60 \%$ of its food today.

Rural farmers in NKR have traditionally practiced subsistence agriculture. During Soviet times, rural families had gardens and household livestock for their own use while working in the commercial communes. Production bonuses for agricultural workers were often paid in kind. For example, a worker in a wheat-growing commune may get a bonus of $1,000 \mathrm{~kg}$ of wheat. When the local economy collapsed during the end of Soviet rule, people just shifted their emphasis entirely to subsistence agricultural practices with surpluses sold through informal markets. Rural families currently grow their own wheat; make their own bread; keep cows to produce cheese, yogurt, and other dairy products; have a household garden/orchard for fruits and vegetables; make their own wine, brandy, and vodka; and harvest wild foods such as walnuts, berries, and mushrooms. Excess production is bartered with neighbors or sold to merchants from Step-

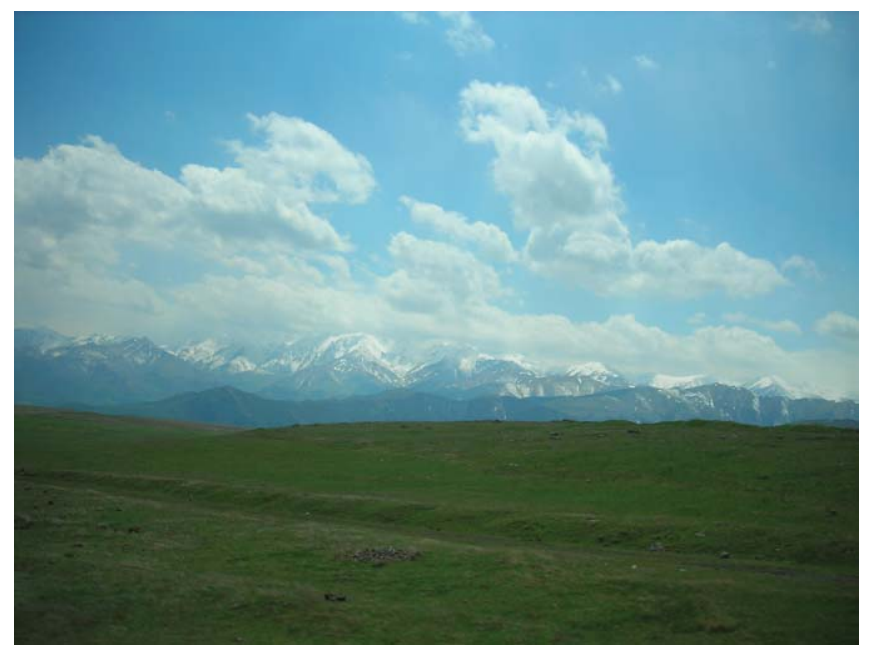

Figure 5. Subalpine grassland in the Karabakh Mountains, NKR. 
anakert or Armenia who visit the villages. Village life has a rather medieval quality. Forage producing lands occupy $57 \%$ of NKR. There are approximately 14,000 pigs, 39,000 cattle, and 40,000 sheep and goats in NKR. ${ }^{7}$ Villages near forests send a herd of pigs out to forage each morning, while a separate herd of cattle or a mixed herd of sheep/goats is herded out to graze open uncropped land. Herds are mixed sex, and males are not castrated. Bulls and boars are left intact so that they will be more aggressive in defending the herd against attack by wolves. One hill village visited lost 60 pigs last year to wolves that came into the village at night and took pigs out of people's fenced yards! Little hay or grain is fed to livestock, so reproductive rates of cattle and sheep are relatively low (often below $50 \%$ calving rate for cows and below $100 \%$ lambing rate for sheep). The little hay that is cut tends to be of low quality because it is often harvested late by hand and transported and stored loose. Sheep and goats consume about $20 \%$ of all forage in NKR, while cattle consume about $80 \%$ of the forage used for livestock production. Although cattle are found both in the mountains and in the plains, sheep and goats tend to be more concentrated in the mountains, where their shorter lactation period and shorter reproductive cycle make them more able to deal with high seasonal variability in forage quantity and quality. Sheep are primarily the fat-tailed type preferred as meat animals in Iran, North Africa, and the Middle East region. Exports of live sheep to these areas may be a viable and lucrative future market opportunity. Both sheep and goats are often kept as small household livestock that provide rural farmers with milk and meat for their own use. They are also important sources of hair for textiles and carpet making. The Caucasus region, along with nearby Iran, are well respected traditional carpet making areas.

Because of its political isolation, NKR receives little foreign aid or economic assistance from the international community. Money for economic development and construction of basic infrastructure comes from private charities such as Catholic Relief Services and the Hayastan All-Armenia Fund. The Armenia Fund has been actively building roads, schools, clinics, hospitals, water pipelines, and other basic infrastructure in NRK for many years. An ambitious 5year project of economic development through agricultural modernization was added to the portfolio of infrastructure projects in 2006. Bread is the basis for rural diets. Karabakh wheat is in demand in Armenia because its high gluten content makes it desirable for bread production. Current wheat production is well below that needed to supply both domestic and export markets. The development strategy is to initially focus on supporting and improving cereal production by importing new modern tractors, harvesters, and field implements so that land can remain in production. Access to fertilizers, improved seeds, and, to a lesser extent, agricultural chemicals, together with improved farming practices, should increase cereal yields. Modern equipment to cut and bail hay is also being imported. This is meant to be the first stage in a successional process moving up the value-added ladder from basic commodities such as wheat and corn to processed products such as processed meats, dairy products, dried fruits, and jams and jellies. Prices for meat are relatively high, and there is considerable potential to increase meat production and rural household income by improved pasture and livestock husbandry without saturating local markets. ${ }^{6} \mathrm{~A}$ few hill farmers have begun to increase hog production as a way of marketing excess grain. It is hoped that using grain to support animal production will become more common as wheat yields increase and other grains more suitable for animal production, such as oats, corn, and barley, are again grown. Once sufficient excess animal products are consistently available, processing businesses can follow.

The opportunity to finish forage-raised livestock on grain may place additional stress on NKR's forest and pasture resources by encouraging expansion of livestock populations. Currently, local graziers do not perceive overuse of pastures and forests as being a problem despite some evidence to the contrary. The land tenure situation in NKR is very amenable to allocating forage resources at the village level. In addition, some of the lower-producing croplands may be more economically used as improved pastures. Although planting agronomic pasture is rare in Karabakh, their use along with cereal grains for more intensive livestock production may be more profitable than wheat production. This opens up possibilities to reduce pressure on grazing lands surrounding villages.

Karabakhes realize that their quality of life is tied to the health of their farms, forests, and pastures. While much work remains to be done, there is every reason to be optimistic that a reasonable balance between economic rejuvenation and environmental quality will be achieved so that Nagorno Karabakh truly becomes a Shangri-La.

Author is Professor, Department of Rangeland Ecology and Management, Oregon State University, Corvallis. NKR activities are as a consultant to the Hayastan All-Armenia Fund, steven. h.sharrow@oregonstate.edu.

\section{References}

1. Jrbashyan R., G. Chlingaryan, Yu. Kagramanov, A. Karapetyan, M. Satian, Yu. Sayadyan, and H. Mkrtchyan. 2001. Geology of Meso-Cenozoic basins in Central Armenia, with comment on indications of hydrocarbons. Search and Discovery article \#30007. Available at http://www. searchanddiscovery.net/documents/armenia/index.htm.

2. Conservation International. 2006. Biodiversity hot spots: Caucasus. Available at http://www.biodiversityhotspots.org/ $\mathrm{xp} /$ Hotspots/caucasus/.

3. [UNEP] United Nations Environmental Program. 2002. Caucasus environmental outlook 2002. United Nations Environmental Program. Available at http://www.grid.unep.ch/ product/publication/CEO-for-Internet/CEO/index.htm

4. [WWF] World Wildlife Fund. 2001. Biodiversity of the Caucasus Ecoregion: an analysis of biodiversity and current 
threats and initial investment portfolio. Tbilisi, Georgia: World Wildlife Fund.

5. Heydar Aliyeo Foundation. Undated. Azerbaijan nature. Available at http://www.azerbaijan.az/_Geography/ _Planting/_planting_e.html.

6. Turnaround Associates. 2003. Assessment of the agricultural resources of the Nagorno Karabakh Republic. New York, NY: Turnaround Associates. 39 p.
7. Ministry of Agriculture. 2003. Agriculture of the Nagorno Karabakh Republic - background data. Stepanakert, NKR: Ministry of Agriculture. $32 \mathrm{p}$.

8. Balayan, S. 2004. Cut trees but selectively. Available at http:// www.armeniandiaspora.com/forum/showthread.php?t=9907.

9. Baghdasaryan, E. 2003. Martuni or bust!!! Available at http://aramanoogian; Blogspot.com/2003/10/association-ofinvestigativw.html.

\section{BoOst Your Profits TOdAY!}

\section{ADVERTISE IN \\ RANGELANDS}

AND

\section{Journal of Range Management}

Reach nearly 4,000 rangeland managers, scientists, educators, students, producers and conservationists who are waiting to support businesses who advertise in their favorite journals! With full page rates starting as low as $\$ 750$, you can maximize exposure without breaking the bank. This is one opportunity that you cannot afford to miss!

\section{Call Today! 800-627-0932, ext. 262}

